\title{
OVULATION AND CORPUS LUTEUM MAINTENANCE IN EWES TREATED WITH 17 $\beta$-OESTRADIOL*
}

\author{
EDGAR L. PIPER $\dagger$ AND WARREN G. FOOTE \\ Department of Animal Science, Utah State University, Logan, Utah
}

(Received 10th Fuly 1967)

\begin{abstract}
Summary. Two experiments designed to measure the influence of oestradiol on ovulation and cL maintenance in cycling ewes are reported. All oestradiol-treated ewes were given a single injection of oestradiol on the 4th day of their oestrous cycle; in addition, some ewes were given continuous daily injections of progesterone or oestradiol. Ovarian condition was determined by gross observations in Exp. 1 and by gross and histological observations in Exp. 2. Oestradiol induced ovulation in 72 and $73 \%$ of the ewes in Exps. 1 and 2, respectively. Progesterone blocked the ovulatory response to oestradiol. Continued daily injections of oestradiol were effective in maintaining the GL and inhibiting follicular development. The oestrous behaviour exhibited by oestradiol-treated ewes was not associated with ovulation. Induction of ovulation by oestrogen is probably due to a release of $\mathrm{LH}$. The luteotrophic nature of oestrogen in the ewe may be caused by an increase in prolactin secretion. LH as a luteotrophic factor is suggested.
\end{abstract}

\section{INTRODUCTION}

It is well established that oestrogens play an important role in regulation and control of reproductive processes in the female. However, little information is available concerning the mechanisms affected, the modifying influence of oestrogen levels, the effects of varied types of oestrogens or their interactions with progestagens on these mechanisms.

Infrequent reports indicate that oestrogen can elicit an ovulatory response in both anoestrous ewes (Hammond, Hammond \& Parkes, 1942; Vandernoot, Reece \& Skelley, 1949) and cycling ewes (Casida, 1946; Waite \& Foote, 1962). Sufficient evidence is not yet available to draw conclusions about the mechanisms involved.

The studies reported here were designed to provide more information on the influence of oestradiol on the induction of ovulation in the cycling ewe and on corpus luteum function.

\footnotetext{
* Published with the approval of the Utah Agricultural Experiment Station as Paper No. 695.

$\dagger$ Present address: Department of Animal Science, University of Arkansas, Fayetteville, Arkansas, U.S.A.
} 


\section{Experiment 1}

\section{MATERIALS AND METHODS}

Forty-five mature, white-faced (Columbia-Rambouillet) ewes were randomly assigned to four groups. Treatments were started in November 1963 and continued through to January 1964. Animals in Group 1 served as a control group and received no injections. Animals in Group 2 received $2 \mathrm{mg}$ of $17 \beta$ oestradiol on Day 4 of their cycle (Day 0 was the first day of oestrus). The ewes in Group 3 received $2 \mathrm{mg}$ of oestradiol on Day 4 and $1 \mathrm{mg}$ of oestradiol daily from Day 5 to Day 24. The ewes in Group 4 received $2 \mathrm{mg}$ of oestradiol on Day 4 and $5 \mathrm{mg}$ of progesterone given daily from Day 3 to Day 24 .

All hormones were dissolved in corn oil and given intramuscularly. Oestrus was determined with painted vasectomized rams and checks were made at approximately $12-\mathrm{hr}$ intervals. Only ewes exhibiting one normal pre-treatment cycle (15 to 18 days) were used in the study.

All ewes were routinely laparotomized on Days 8 and 16, using local anaesthesia. Some ewes were laparotomized again on Day 24 and autopsied at a later date. Date of autopsy was based on the condition of the CL at laparotomy. The remaining ewes were autopsied on Day 24. At autopsy and laparatomy, the ovaries were examined and the number of $\mathrm{CL}$ with their location, type (natural or induced) and condition (young, mature, regressed) were noted. The naturally occurring GL were marked with India ink on Day 8. The size and number of follicles $2 \mathrm{~mm}$ or greater were also recorded.

Some laparotomies were performed in the oestrogen-treated group on Day 4 and the cL marked and checked again by laparotomy on Day 8 to establish differences between the naturally occurring and oestrogen-induced CL. Obvious differences in development resulting from age made them easily distinguishable.

\section{Experiment 2}

Fifty mature, cycling (Rambouillet-Columbia) ewes (selected as described in Exp. 1) were randomly assigned to six groups. The experimental period began in October 1964 and ended in December 1964. Ewes in Group 1 (control group) received no injections. Animals in Group 2 received $2 \mathrm{mg}$ of $17 \beta$-oestradiol on the 4th day of the cycle. Ewes in Groups 3,4 and 5 received the same treatment as Group 2 plus $0.5,1.5$ and $2.5 \mathrm{mg}$ of oestradiol from Day 5 through to Day 22, respectively. The ewes in Group 6 were killed on the first day of their cycle, their ovaries were removed, and the regressing cL, which were approximately 17 to 19 days old, were fixed for histological analysis.

Laparotomies were performed on all ewes in Groups 1 to 5 on Days 8, 14, 18 and 22. One or both ovaries were removed surgically from some ewes beginning at Day 22 and fixed for histological analysis. The remainder of the ewes that exhibited maintained CL at the previous laparotomy were laparotomized again after an additional 15 days.

The number, location and condition of the CL and the number and size of the follicles were noted. During the laparotomy on Day 8, the induced CL were marked with India ink. The control ewes (Group 1) were slaughtered on the 10th day of the subsequent cycle and their ovaries removed and fixed for histological 
analysis. All ovaries were fixed in $10 \%$ formalin and stained with Shorr's triple stain.

Painted, vasectomized rams were with the ewes continuously; checks for oestrus were made twice daily. Statistical differences were determined in both experiments using chi-square techniques.

\section{TABLE 1}

EXPERIMENT 1. THE MEAN EFFECT OF $17 \beta$-OESTRADIOL AND PROGESTERONE ON OVULATION, CL MAINTENANCE AND FOLLIGULAR DEVELOPMENT

\begin{tabular}{|c|c|c|c|c|}
\hline Group & Treatment & $\begin{array}{c}\text { Ewes with } \\
\text { oestrogen-induced } \\
\text { CL } \\
(\%)\end{array}$ & $\begin{array}{c}\text { Maintenance of } \\
\text { natural and induced } \\
\mathrm{CL}^{*} ; 24 \text { th day of cycle } \\
(\%)\end{array}$ & $\begin{array}{c}\text { Follicular development } \\
\text { at Day } 16 \text { of treatment } \\
\text { cycle; ewes with at } \\
\text { least one follicle }>6 \mathrm{~mm} \\
(\%)\end{array}$ \\
\hline $\begin{array}{l}1 \\
2 \\
3 \\
4\end{array}$ & $\begin{array}{l}\text { Control } \\
\text { Oestradiol } \\
\text { Oestradiol }+ \\
\text { oestradiol daily } \\
\text { Oestradiol }+ \\
\text { progesterone daily }\end{array}$ & $\begin{array}{r}0^{\mathrm{a}} \\
77^{\mathrm{b}} \\
67^{\mathrm{b}} \\
20^{\mathrm{a}}\end{array}$ & $\begin{array}{l}0^{\mathrm{a}} \\
8 \cdot 3^{\mathrm{a}} \\
50 \cdot 0^{\mathrm{b}} \\
0^{\mathrm{a}}\end{array}$ & $\begin{array}{r}80^{a} \\
53^{a} \\
0^{b} \\
80^{a}\end{array}$ \\
\hline
\end{tabular}

1,b Values in the same column not bearing the same superscript differ significantly $(P<0.05)$.

* The patterns of regression were similar for natural and induced cL.

TABLE 2

EXPERIMENT 2. THE MEAN EFFECT OF $17 \beta$-OESTRADIOL ON OVULATION, CL MAINTENANCE AND FOLLICULAR DEVELOPMENT

\begin{tabular}{|c|c|c|c|c|c|}
\hline \multirow[t]{2}{*}{ Group } & \multirow[t]{2}{*}{$\begin{array}{c}\text { Treatment } \\
\text { Day of oestrous cycle } \\
4 \quad 5 \text { to } 22\end{array}$} & \multirow[t]{2}{*}{$\begin{array}{c}\text { Ewes with } \\
\text { oestradiol-induced } \\
\text { CL } \\
(\%)\end{array}$} & \multicolumn{2}{|c|}{$\begin{array}{c}\text { Maintenance of } \\
\text { natural and induced } \\
\mathrm{CL}^{*} \\
\text { Days of treatment } \\
\text { cycle }\end{array}$} & \multirow{2}{*}{$\begin{array}{l}\text { Follicular development } \\
\text { at Day } 14 \text { of treatment } \\
\text { cycle; ewes with at } \\
\text { least one follicle } 6 \mathrm{~mm} \\
\text { or }> \\
(\%)\end{array}$} \\
\hline & & & $\begin{array}{c}22 \\
(\%)\end{array}$ & $\begin{array}{c}37 \\
(\%)\end{array}$ & \\
\hline $\begin{array}{l}1 \\
2 \\
3 \\
4 \\
5\end{array}$ & $\begin{array}{l}\text { No injection } \\
2 \mathrm{mg} \dagger \\
2 \mathrm{mg}+0.5 \mathrm{mg} \\
2 \mathrm{mg}+1.5 \mathrm{mg} \\
2 \mathrm{mg}+2.5 \mathrm{mg}\end{array}$ & $\begin{array}{c}0^{\mathrm{a}} \\
70^{\mathrm{bc}} \\
44^{\mathrm{b}} \\
100^{\mathrm{c}} \\
86^{\mathrm{c}}\end{array}$ & $\begin{array}{l}0^{\mathrm{a}} \\
20^{\mathrm{a}} \\
56^{\mathrm{bc}} \\
86^{\mathrm{c}} \\
100^{\mathrm{c}}\end{array}$ & $\begin{array}{c}0^{\mathrm{a}} \\
10^{\mathrm{ab}} \\
20^{\mathrm{ab}} \\
40^{\mathrm{bc}} \\
100^{\mathrm{c}}\end{array}$ & $\begin{array}{l}62 \cdot 5^{\mathrm{a}} \\
80^{\mathrm{a}} \\
0^{\mathrm{b}} \\
12^{\mathrm{b}} \\
0^{\mathrm{b}}\end{array}$ \\
\hline
\end{tabular}

a,b,c Values in the same column not bearing the same superscript differ significantly $(P<0.05)$.

* The patterns of regression were similar for natural and induced CL.

$\dagger$ Levels used and duration of $17 \beta$-oestradiol injections.

\section{RESULTS}

Results are summarized in Tables 1 and 2 . Ovulation was induced in $72 \%$ of ewes injected with $2 \mathrm{mg} 17 \beta$-oestradiol on the 4th day of the oestrous cycle (Groups 2 and 3) in Exp. 1 and 73\% in Exp. 2. Oestradiol-induced ovulation was significantly inhibited by progesterone treatment (Exp. 1, Group 4, 20\% versus Group 2, 77\%). 
Sixty-seven per cent of the ewes in Exp. 1 and $76.7 \%$ of the ewes in Exp. 2 (mean of Groups 3, 4 and 5) which received daily injections of oestradiol maintained both their natural and oestradiol-induced cL until the end of the oestradiol injection period (Tables 1 and 2). All of the ewes which received 2.5 mg of oestradiol (Day 5 to Day 22, Table 2, Group 5) exhibited active cL on the 37 th day of the treatment cycle. One ewe in this group (Group 5) was ovariectomized on the 52nd day of her treatment cycle; her CL appeared grossly and histologically functional.

The oestrogen-induced $\mathrm{CL}$ appeared to follow the same pattern of regression as the natural CL. The CL from treated ewes taken at the $22 \mathrm{nd}, 37$ th or $52 \mathrm{nd}$ day of the cycle usually showed some regressive changes, e.g. the lutein cells and their nuclei were smaller. The well-organized cellular structure and the lack of connective tissue invasion of the oestrogen-treated and the 10-day control CL compared with the 17- to 19-day-old control GL (Pl. 1, Figs. 1 to 4) indicated that oestrogen-treated GL were functional. Recent determination of ovarian vein and CL progesterone of oestrogen-treated ewes demonstrated that these GL are capable of secreting progesterone.

Continued daily injections of oestradiol resulted in relative follicular arrest. This was demonstrated by the significant $(P<0.05)$ decrease in follicular development in these groups in both Exps. 1 and 2 (Tables 1 and 2).

With one exception in Exp. 1, those ewes receiving continued oestradiol injections (Group 3) failed to re-ovulate. The one ewe that re-ovulated did so 3 weeks or longer after the natural and induced cL had apparently regressed and 2 weeks or longer after the end of oestradiol treatment. Especially in Exp. 1, a large proportion of the ewes demonstrated a period of relative ovarian inactivity. The length of time until re-ovulation varied from several days to 3 or more weeks.

\section{DISCUSSION}

Oestrogen-induced ovulations were reported by Hammond et al. (1942) and Vandernoot et al. (1949) in anoestrous ewes. Casida (1946) reported that stilboestrol could induce ovulation in cycling ewes and Waite \& Foote (1962) found that $17 \beta$-oestradiol induced ovulation during the 7 th to $1 \mathrm{I}$ th day of the oestrous cycle in sheep. Oestradiol was most effective in inducing ovulation during the early stages of the oestrous cycle (Waite, 1962). Progesterone-primed cows have been induced to ovulate with oestradiol (Ulberg \& Lindley, 1960).

It has been shown that oestrogens act directly on the hypothalamo-hypophysial complex. Oestrogen-sensitive centres have been found in the median eminence region of the hypothalamus in the rat and rabbit. Oestradiol implants

EXPLANATION OF PLATE 1

Photomicrographs of sheep CL. $\times 438$.

Figs. 1 and 2. CL of ewes receiving no treatment. Fig. 1, removed on the 10th day of the oestrous cycle. Fig. 2, a 19-day-old cL removed on the 1st day of the subsequent cycle.

Figs. 3 and 4 . CL of ewes which were receiving $2.5 \mathrm{mg}$ of oestradiol daily from Day 5 to Day 22 (Exp. 2, Group 5). Fig. 3, removed on the 52nd day of the cycle. Fig. 4, removed on the 22 nd day. 
PLATE 1

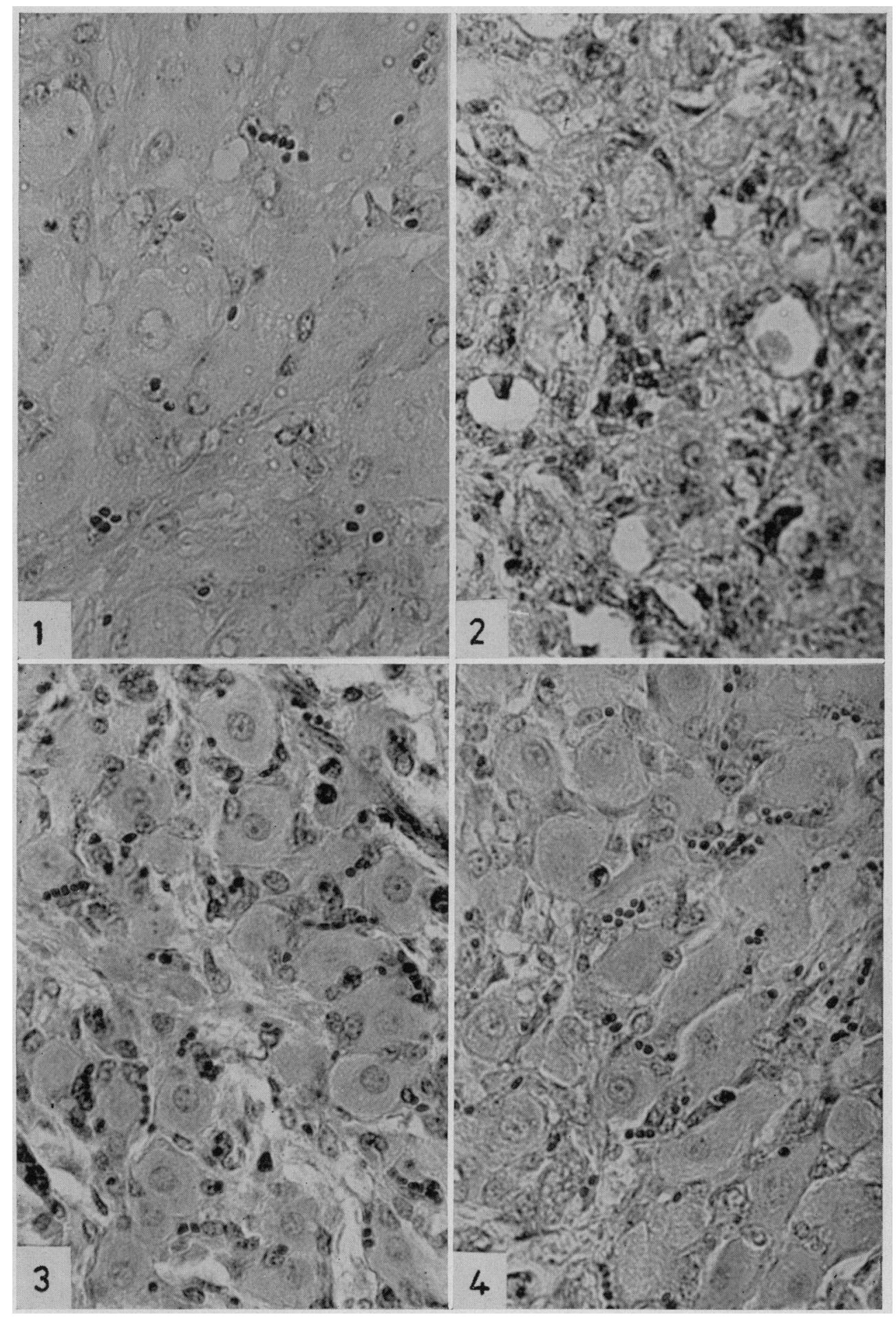

(Facing p. 256) 
in the median eminence have resulted in an initial decrease in the pituitary $\mathbf{L H}$ content in the rat (Ramirez, Abrams \& McGann, 1964) and rabbit (Kanematsu \& Sawyer, 1964). Implants of oestradiol in the hypophysis produce an initial increase in plasma LH in the rabbit. It is possible that, in the ewe, oestradiol also causes an initial release of pituitary LH. Soliman, Nasr, Abdo \& Soliman (1963) found that, in ovariectomized ewes, oestrogen plus progesterone decreased pituitary LH and increased serum LH. Johnson (1964) prepared an LH-releasing factor from the sheep hypothalamus.

Oestrogen has been shown to be luteotrophic in rats (Merckel \& Nelson, 1940), rabbits (Robson, 1937), horses (Nishikawa, Sugie, Onuma \& Fujisaki, 1958), swine (Gardner, First \& Casida, 1963) and lambs (Denamur \& Mauléon, 1963); however, oestrogen is luteolytic in cattle (Wiltbank, Ingalls \& Rowden, 1961 ; Niswender, Kaltenbach, Shumway, Wiltbank \& Zimmerman, 1965) and hamsters (Greenwald, 1965). The mechanism by which oestrogens act to influence GL function is not clear. The luteotrophic factor in the ewe has not been identified. Denamur \& Mauléon (1963) found that oestradiol but not prolactin was luteotrophic in intact prepuberal lambs. When they hypophysectomized and induced ovulation in prepuberal lambs, neither oestrogen nor prolactin maintained the CL. Prolactin, but not oestrogen, has been shown to be luteotrophic in hypophysectomized, hysterectomized lambs (Thibault, 1966). Exogenous oestrogen resulted in prolactin synthesis and secretion in the rat (Ramirez \& McCann, 1964) and rabbit (Kanematsu \& Sawyer, 1963). The luteotrophic nature of oestrogen in the ewe may be due to a release of prolactin. Short (1964) was unable to demonstrate an increase in the secretory activity of the CL on the ewes with FSH, LH, HCG, AGTH, PMSG, TSH, endometrial extracts or sheep pituitary extracts. Since oestrogen can result in LH release, the luteotrophic nature of oestrogen may be in part due to the release of LH. The reason CL were maintained for at least 15 to 30 days after oestrogen injections were stopped is not understood. Similar observations were made in the pig (Nishikawa et al., 1958).

Oestrogen may have a direct luteotrophic effect on the CL as was demonstrated by Hammond \& Robson in the rabbit (1951). Robson (1939) suggested that oestrogen may control the luteal function of pregnant rabbits. Keyes \& Nalbandov (1967) stated that oestrogen is necessary to maintain the GL of pregnant rabbits. In addition, oestradiol may increase the sensitivity of the ovary to LH as pointed out by Bradbury (1961) in the rat. However, in a preliminary study, Le Fever, Nelms, Nolan \& Stratton (1965) applied oestrogen systemically or directly to the ovaries of immature and anoestrous ewes but failed to find convincing evidence of a direct action.

Circumstantially from these data, it would appear that oestrogen initially facilitates release of $\mathbf{L H}$ and continued injection inhibits the release of FSH. Parlow (1964) reported that in the rat, $2 \mu \mathrm{g}$ of oestradiol administered systemically inhibited the post-ovariectomy elevation of pituitary and serum FsH. The FSH content of male rat pituitaries was reduced by doses of oestradiol ranging from 0.004 to $0.4 \mathrm{mg} / \mathrm{kg} /$ day (Beyler \& Potts, 1962). Soliman et al. (1963) found that in ovariectomized sheep, $20 \mu \mathrm{g}$ of oestradiol did not significantly affect pituitary or serum FSH levels. However, $20 \mu \mathrm{g}$ oestradiol plus 20 
$\mathrm{mg}$ of progesterone decreased pituitary FSH but did not affect serum FSH. The depressing effect of oestradiol on follicular development may be caused by the inhibitory action of oestradiol on FSH synthesis which would depress follicular growth.

In many animals, continued daily injections of oestradiol produced recurring oestrous behaviour. The oestrous behaviour exhibited by the treated ewes was not necessarily associated with ovulation. Oestrous was probably a direct response to oestradiol injection in many cases.

Waite (1962) reported that ovulation was induced with oestradiol more frequently during the early rather than the latter part of the oestrous cycle and suggested that this might be related to differences in levels of progesterone. The inhibiting influences of exogenous progesterone described in this paper tend to bear this out.

\section{ACKNOWLEDGMENTS}

This work was supported in part by National Institutes of Health Grants No. HD-00499 and GM-11035.

\section{REFERENCES}

Beyler, A. L. \& PotTs, G. O. (1962) Influence of gonadal and adrenal cortical hormones on estrogeninduced depletion of pituitary gonadotropin content. Endocrinology, 70, 611.

Bradbury, J. T. (1961) Direct action of estrogen on the ovary of the immature rat. Endocrinology, 68, 115.

CAsIDA, L. E. (1946) Induction of ovulation and subsequent fertility in domestic animals. In: The Problem of Fertility. Ed. Earl T. Engle. Princeton University Press, Princeton, New Jersey.

Denamur, R. \& Mauléon, P. (1963) Contrôle endocrinien la persistance du corps jaune chez les ovins. C.r. hebd. Séanc. Acad. Sci. 257, 527.

Gardner, M. L., First, N. L. \& CAsida, L. E. (1963) Effect of exogenous estrogens on corpus luteum maintenance in gilts. F. Anim. Sci. 22, 132.

GreEnwald, G. S. (1965) Luteolytic effect of estrogen of the corpora lutea of pregnancy of the hamster. Endocrinology, 76, 1213.

Hammond, J., JR, Hammond, J. \& Parkes, A. S. (1942) Hormonal augmentation of fertility in sheep. I. Induction of ovulation, superovulation and heat in sheep. f. agric. Sci. 32, 308.

HAMmond, J., JR \& RoBson, J. M. (1951) Local maintenance of the rabbit corpus luteum with oestrogen. Endocrinology, 49, 384.

Jornson, D. G. (1964) Preparation of a luteinizing hormone releasing factor from sheep hypothalamus. Experientia, 20, 311.

Kanematsu, S. \& SaWYeR, C. H. (1963) Effects of hypothalamic estrogen implants on pituitary LH and prolactin in rabbits. Am. F. Physiol. 205, 1073.

Kanematsu, S. \& SAWYer, C. H. (1964) Effects of hypothalamic and hypophysial estrogen implants on pituitary and plasma $\mathrm{LH}$ in ovariectomized rabbits. Endocrinology, 75, 579.

Keyes, P. L. \& Nalbandov, A. V. (1967) Maintenance and function of corpora lutea in rabbits depend on estrogen. Endocrinology, 80, 938.

LeFever, D. G., Nelms, G. E., Nolan, J. C. \& Stratton, P. O. (1965) Direct effect of low levels of estradiol on ovaries of immature and anestrous ewes. Proc. West. Sec. Am. Soc. Anim. Sci. 16, xvi.

Merckel, C. \& Nelson, W. O. (1940) The relation of the estrogenic hormone to the formation and maintenance of corpora lutea in mature and immature rats. Anat. Rec. 76, 391.

Nishikawa, Y., Sugie, T., OnUma, H. \& Fujisaki, T. (1958) Effect of continuous injection of oestrogen in the reproductive function of domestic animals. XIV. Effect on the maintenance of corpus luteum with special reference to the kinds of animals. Bull. natn. Inst. agric. Sci., Tokyo, 14, 45, Anim. Breed. Abst. 26, 363.

Niswender, G. D., Kaltendach, G. C., Shumway, R. P., Wiltbank, J. N. \& Zimmerman, D. R. (1965) Alteration of ovarian activity in cycling beef heifers with small daily injections of estradiol. 7. Anim. Sci. 24, 986.

Parlow, A. F. (1964) Differential action of small doses of estradiol on gonadotrophins in the rat. Endocrinology, 75, 1. 
Ramirez, V. D., Abrams, R. M. \& McCanN, S. M. (1964) Effect of estradiol implants in the hypothalamo-hypophysial region of the rat on the secretion of luteinizing hormone. Endocrinology, $75,243$.

Ramirez, V. D. \& McCann, S. M. (1964) Induction of prolactin secretion by implants of estrogen into the hypothalamo-hypophysial region of female rats. Endocrinology, 75, 206.

Robson, J. M. (1937) Maintenance by oestrin of the luteal function in hypophysectomised rabbits. F. Physiol. 90, 435.

Robson, J. M. (1939) Maintenance of pregnancy in the hypophysectomised rabbit by the administration of oestrin. F. Physiol. 95, 83 .

Short, R. V. (1964) Ovarian steroid synthesis and secretion in vivo. In: Recent Progress in Hormone Research. Ed. Gregory Pincus. Academic Press, London.

Solman, F. A., Nasr, H., Abdo, M. S. \& Sollman, M. K. (1963) Effects of oestradiol and progesterone on FSH and LH contents of the pituitaries and blood of ovariectomized ewes. Experientia, $19,430$.

Thrbaut., G. (1966) Luteal maintenance in hypophysectomized and hysterectomized sheep. F. Reprod. Fert., Suppl. 1, 63.

UlberG, L. C. \& LINDLey, G. E. (1960) Use of progesterone and estrogen in the control of reproductive activities in beef cattle. 7 . Anim. Sci. 19, 1132.

Vandernoot, G. W., Reece, R. P. \& Skelley, W. C. (1949) Influence of estrogen alone and in conjunction with pregnant mare serum in anestrous ewes. 7 . Anim. Sci. 8, 583.

WArTe, A. B. (1962) Some effects of estradiol on estrus and ovulation in the ewe. M.S. thesis, Utah State University.

Warte, A. B. \& Foore, W. C. (1962) Some effects of level of estradiol on estrus and ovulation in the ewe. Proc. West. Sec. Am. Soc. Anim. Sci. 13, vi.

WILtBank, J. N., INGAlls, J. E. \& RowDen, W. W. (1961) Effects of various forms and levels of estrogens alone or in combinations with gonadotrophins and the estrous cycle of beef heifers. $\mathcal{F}$. Anim. Sci. 20, 341. 